\title{
CONSUMER PREFERENCES ON TRADITIONAL FISHERIES PROCESSING PRODUCT TO SUPPORT SUSTAINABLE FISHERIES BUSINESS IN LAMPUNG PROVINCE
}

\section{Preferensi Konsumen terhadap Produk Olahan Tradisional dalam Mendukung Usaha Perikanan Berkelanjutan di Provinsi Lampung}

\author{
Helvi Yanfika ${ }^{1, *}$, Abdul Mutolib ${ }^{1)}$, Siti Amanah'²), Anna Fatchiya ${ }^{2)}$, Pang S. Asngari ${ }^{2)}$
}

${ }^{1}$ Study Program of Agricultural Extension, Faculty of Agriculture, University of Lampung, Bandar Lampung 35145, Indonesia

${ }^{2}$ Department of Communication Science and Community Development, Faculty of Human Ecology, IPB University, Bogor 16688, Indonesia

${ }^{*}$ E-mail: helviyanfika@yahoo.co.id

\section{ABSTRACT}

The choice of marketing strategy is determined by consumer perceptions. This study aimed to analyze the consumer preferences on purchasing traditional fisheries processing products from salting, smoking, fermentation, and brining. Samples were taken from the consumers of Kota Agung Market in Tanggamus Regency, Sukadana Market in East Lampung Regency, and Gintung Market in Bandar Lampung City. Respondents were determined using accidental sampling method, resulting in 99 respondents. This study was conducted from July to September 2017. Data obtained were analyzed using qualitative descriptive method. The survey results characterized the idea that consumers purchased more traditional processing products on weekend (Saturday-Sunday), rather than on weekdays (Monday-Friday). The results of this study proposed that the traditional fisheries processing products, namely salted, brined, smoked, and fermented fish had the same quality in all markets. The most quality preferences considered are: flavor, price, product color, packaging type, and package color. High consumer assessment has an impact on sustainable traditional fisheries processing business development. Consumers assessed that the processing products had good taste, good aroma, fresh appearance, clear color, and solid texture.

Key words: Consumer, Fisheries, Preferences, Processing Product, Traditional

\section{ABSTRAK}

Pilihan strategi pemasaran sangat ditentukan oleh persepsi konsumen. Penelitian bertujuan untuk menganalisis preferensi konsumen terhadap pembelian produk hasil olahan tradisional perikanan dengan jenis hasil olahan penggaraman ikan, pengasapan ikan, fermentasi ikan dan pemindangan ikan. Sampel dalam penelitian ini adalah konsumen di Pasar Kota Agung Kabupaten Tanggamus, Pasar Sukadana Kabupaten Lampung Timur, dan Pasar Gintung Kota Bandar Lampung. Penentuan responden menggunakan metode accindental sampling dengan 99 orang. Penelitian dilaksanakan pada bulan Juli sampai September 2017.Data di analisis dengan pendekatan deskriptif kualitatif.Hasil penelitian memberikan gambaran bahwa konsumen lebih banyak membeli produk hasil olahan tradisional perikanan pada week end (Sabtu-Minggu) dibandingkan week days (Senin-Jumat). Preferensi konsumen dalam memilih mutu hasil olahan tradisional penggaraman ikan, pemindangan ikan, pengasapan ikan, dan fermentasi ikan adalah sama. Secara berturut-turut dari yang paling dipertimbangkan sampai dengan yang kurang dipertimbangkan adalah: rasa, harga, warna produk, jenis kemasan, warna kemasan. Tingginya penilaian konsumen memberikan dampak pada usaha olahan tradisonal perikanan akan berkembang dan berkelanjutan. Konsumen menilai produk olahan rasanya enak, memiliki aromanya harum yang khas, penampakkan produk olahan terlihat segar, warna ikan hasil olahan mengkilat, dan tekstur produk olahan padat.

Kata Kunci: Konsumen, Perikanan, Preferensi, Produk Olahan, Tradisional

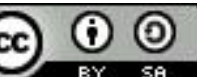

Content from this work may be used under the terms of theCreative Commons Atribusi-BerbagiSerupa 4.0 International. Any further distributionof this work must maintain attribution to the author(s) and the title of the work, journal citation and DOI.

Published under Department of Communication and Community Development Science, IPB University

EISSN : 2442-4110 | E-ISSN : 2442-4110 



\section{INTRODUCTION}

Modern society realizes that the body health is very important, therefore fish and fisheries processing products are consumed. Fish is one of the most important foods in human diet because of its high nutritional quality. They are the well known source of a group of poly unsaturated fatty acids (PUFAs) especially omega-3 and omega-6, which can prevent atherosclerosis and thrombosis. These fatty acids have preventive effects on coronary heart diseases, autoimmune disorders, arrhythmias, lowering plasma triglyceride levels and blood pressure(Kris-Etherton, Harris, \& Appel, 2002;Pal, Shukla, Maurya, \& Verma, 2018). Fisheries processing products are performed in traditional way. Some people involving in traditional processing still have no attention regarding to fish processing standards that meet consumer preferences. This results a business challenges for traditional producers to create good quality processing product based on the food quality standards. One effort to improve the quality of fisheries product is by conducting socialization, dissemination, and practical work on how to produce good traditional processing products made from local raw materials based on the raw material handling and processing procedures, therefore the products will be uniform, safe and qualified as presented on the purpose of Sustainable Development Goals (SDGs), namely the improvement of community nutrition (Pratama, Rostini, \& Kurniawati, 2018). Food safety emerges as a dynamic problem along with the development of human civilization and the advancement of science and technology, thereby requiring a system to supervise food from being produced, processed, handled, transported, stored, distributed, and served to consumers.

Fish is one of most important animal source of food for a healthy diet. It is rich in amino acids, unsaturated fatty acids, vitamins, and trace metals. Furthermore, it is easy to digest due to lack of connective tissue(Burger et al., 1999; Abedi \& Sahari, 2014). Several researchers have investigated the nutritional value of fish and its importance in human diet from various perspectives. Some studies revealed that fish consumption helps preventing cardiovascular diseases, high blood pressure, cholesterol, Alzheimer's disease, and various types of cancer(Barberger-Gateau et al., 2002;McNaughton, Ball, Mishra, \& Crawford, 2008;Pieniak, Verbeke, Perez-Cueto, Brunsø, \& De Henauw, 2008;Verbeke \& Viaene, 1999).The community demand for fish product was higher with $53.7 \%$ than meat (20\%), egg (19.8\%), and milk (6.5\%)(Badan Ketahanan Pangan, 2019). This indicates that fish are still the major source of animal protein in Indonesia as fish contains unsaturated fatty acids, taurine, and omega-3 fatty acids that are good for the human body, making many people prefer increasing the protein consumption derived from fish (Palmquist, 2009)to animal meat as fish have higher nutritional value(Murtidjo, 2008). Furthermore, collaboration is needed to changing consumption habits and preferences of consumers of traditional fisheries processing products among Government agencies, private sector, and occupational organizations(Can, Günlü, \& Can, 2015;Delima, Amanah, \& Tjitropranoto, 2016)

The traditional fish processing business in Lampung Province has not been performed optimally and sustainably ((Manaf, 2007;Nadzan, Setiawan, \& Sukandar, 2008). the processing training and mentoring are given to produce good fish processing product quality, requiring fresh fish raw material and good processing capabilities(Laisa, Sayekti, \& Nugraha, 2013). One factor affecting the quality of processed fishery products in Lampung is the competitiveness of traditional processors (Yanfika, Listiana, Mutolib, \& Rahmat, 2019), in addition, the low competency and knowledge of processors and fishermen is due to the weak communication network with formal information sources such as from extension agents or related agencies(Waryati, Sunarno, Susilawati, \& Leilani, 2019; Listiana, Efendi, Mutolib, \& Rahmat, 2019). Girsang, Rangga, \& Susilawati (2014)found that $3.4 \%$ of fish in Bandar Lampung contains formalin, thus fish producers must have the technical ability to determine fresh raw materials, resulting safe processing product for consumption. Fish consumption, frequency, and preferences are affected by consumers' geographic, social, and cultural characteristics (Conte, Passantino, Longo, \& Voslářová, 2014; Verbeke \& Vackier, 2005). It is known that food preferences are also affected by a number of sensory (taste, smell, texture, and so on) and non-sensory factors (behavior, beliefs, personal characteristics, risk perception, and etc) (Honkanen, Verplanken, \& Olsen, 2006; Dowd \& Burke, 2013). According to Hawkins \& Mothersbaugh(2010), consumer preference is a study of individuals or groups of organizations based on their processes of choosing, securing, utilizing, and disposing products, services, experiences, or ideas, as these processes impact the consumers and community environment. Decision-making process by consumers 
has a stimulus containing several variables which affects the consumer product perception(Helvi Yanfika, Amanah, Fatchiya, \& Asngari, 2018; Effendi et al., 2019). Consumer product perception includes product physical features, packaging design, brand, aroma, taste, and texture. Variables used to measure the consumer preferences for traditional fisheries processing product comprises are taste, color, appearance, aroma and texture.

This study was conducted to identify the consumer final decision making process on fisheries processing product purchase for fulfilling the maximum consumer satisfaction. This study was focused on consumer preference to purchase traditional fisheries processing product, namely salted, brined, smoked, and fermented fish. This study is expected to provide an overview of sustainable traditional fisheries processing product development based on consumer assessment.

\section{METHODS}

This study was conducted in three are as of Lampung Province, namely East Lampung Regency, Tanggamus Regency, and Bandar Lampung City.These areasare the center of traditional processed fish product, i.e salted, brined, smoked, and fermented fish. Consumer preference assessment dataagainst the quality of fish processed products was obtained from the markets located in East Lampung Regency (Sukadana Market), Tanggamus Regency (Kota Agung Market), and Bandar Lampung City (GintungMarket). Gintung Market in Bandar Lampung City is a traditional market that sells traditional processed fish products from East Lampung and Tanggamus Regency. This study was conducted on July-September, 2017.

Respondents for the consumer preference data on traditional fisheries processing products were determined usingaccidental sampling methodfollowing the criteria: Consumers coming to the marker topurchase and consume traditional fisheries processing products, i.esalted, brined, smoked, and fermented fish and willing to be interviewed. Data obtained were accumulated using qualitative descriptive analysis.Accidental sampling technique was used based on the unknown number consideration of consumers coming to purchase the traditional fisheries products with certain quantities, assumingthe consumers wereunlimited. Based on the sampling method used, 99 people were choosen as the respondentsdetailed as 53 people assessed salted fish, 14 people assessed brined fish, 15 people assessedsmoked fish, and 17 people assessed fermented fish (the number of respondents who came to buy and were willing to be interviewed at the appointed time). Therefore, data retrieval related to consumer preference of traditional fisheries processing product quality was limited with several criteria, i.e taste, aroma, freshness, color, and texture. This study is different from other studies on consumer preferences that assess various attributes such as fish size, color, taste, benefits, price, cleanliness, ease of obtaining (Apituley, Stevanus, Risakotta, \& Hiariey, 2017), or research by Suryawati, Saptanto, \& Putri (2017), which assesses consumer preferences in general with categories of like, like, neutral, dislike and very dislike. Attribute determination is adjusted to location specifications. The field survey result obtained from the sellers showed that consumers preferred buying the product on weekends (Saturday-Sunday) to weekdays (Monday-Friday), namely 1:2. Consumer data was limited through time based on hours and weeks with consideration of buyers who came not only on one day and certain hours as well. Buyers come throughout the day so the data collection is divided into three times :

(1) Time

(a) Weekdays(Monday-Friday)

Consumer data were obtained on weekdays in three hour period, namely 1 hour was performed in the morning, afternoond, and evening respectively.

(b) Weekends (Saturday-Sunday)

Consumer data were obtained on weekends in six hour period, namely two hours were performed in the morning, afternoon, and evening.

(2) Week period

Data were obtained for three weeks under the proportion:

(a) Week 1 (Monday-Sunday) in Sukadana Market, Lampung Timur Regency

(b) Week 2 (Monday-Sunday) in Kota Agung Market, Tanggamus Regency

(c) Week 3 (Monday-Sunday) in Gintung Market, Bandar Lampung City 


\section{RESULT AND DISCUSSION}

Activities of fisheries business for fisheries development are very closely related to the consumer. Consumer behavior is essentialdecision taken by consumers using available resources, such as time, money, and effort, to be exchanged for consumed goods. Simple consumer behavior includes decisions about what they buy, why, where, when, and how often they buy. The results of this study were supported by (Herlambang et al., 2011) on consumer behavior study of herbal tea marketing strategy in Bogor explained that price factor has positive relationship in determining the consumer decision, as prices liked by many circles is relatively affordable price, thus being the most distinct priority among the community. Consumers in making decisions have a stimulus containing several variables which affect the consumer product perception. Consumer assessment of processed products include flavor, aroma, appearance, color and texture. In general, all respondents want an affordable price to meet their daily needs (Tjiptono, 2007; Sugiarto \& Subagio, 2014). Buyers usually view prices as an indicator of the quality of a service, especially for services that have conditions where quality is difficult to detect before the service is consumed(Angelova \& Zekiri, 2011).Consumer preference is the choice of likes or dislike of the product (goods or services) consumed. Preferences show consumer likes from the available product options(Creusen \& Schoormans, 2005; Chung \& Rao, 2012). The assessment criteria of fisheries products obtained were flavor, aroma, freshness, color, and texture.

Table 1. Consumer Educational Background on Traditional Fisheries Processing Products

\begin{tabular}{lcc}
\hline \multicolumn{1}{c}{ Formal Education } & Consumer (people) & Percentage (\%) \\
\hline Elementary school & 25 & 25.3 \\
Middle School & 23 & 23.2 \\
High School & 42 & 42.4 \\
Diploma/ & & \\
Bachelor & 9 & 9.1 \\
\hline Total & 99 & 100.0 \\
\hline
\end{tabular}

The survey result showed that traditional fisheries processing products in Lampung were affordable, making the good product demand. Consumers of traditional fisheries processing product were mostlyfrom high school educationas seen in Table 1. Good educational conditions will affect the consumer perception in providing product assessment. According to Van den Ban and Hawkins (1999), education is the means to form opinions and courage in decision making.

\section{Salted fish}

Salted fish production inLabuhanMaringgai and PasirSakti District in East Lampung and Kota AgungDistrict in Tanggamus Regency comprised saltedanchovy, boiled salted fish and chopped salted fish. Salted anchovywas obtained from the sea boiled using salt mixed with water at 1:5-1:10 salt ratio. $10 \mathrm{~kg}$ of anchovy was mixed with $1 \mathrm{~kg}$ of salt, then boiled and dried under the sunlight to producesalted anchovy. Fish used was obtained from the sea near the production site. The producerpurchased anchovy at $\mathrm{Rp} 17,000 / \mathrm{kg}$, the boat owner system loan the boat to the fisherman, then boat fuel costs and damage to the boat was in charge of the boat owner, but the fisherman was obliged to sell their fish to the boat owner and the price of raw fish to make boiled salted fish wasRp 3,000-6,000/kgfish.

Most of the boiled or salted fish producres have boats to catch the fish around LabuhanMaringgaiDistrict waters as well aspurchasing the fish fromfishermen on other regions, such as Kalianda, South Lampung Regency when excessive raw materials and boiling owner or salted fish in Kaliandawasunable to accommodate and process the fish.The process of salted fish production in Lampung Province mostly uses dry-cleaning techniques.Salt used by fishermen or producers to work on fish catches is in the form of bulk salt, as it is economically cheaper and easier to obtain. There are two kinds of salting techniques, namely wet and dry salting. Dry salting is common salting technique that uses salt crystals mixed with fish (Budiman, 2013). Process of salting used salt $(\mathrm{NaCl})$ as preservative medium, both formed crystals and solutions (Albarracín, Sánchez, Grau, \& Barat, 2011;Bonoco \& Kurt Kaya, 2018). 
Table 2. Consumer assessment on Salted Fish Product Quality

\begin{tabular}{|c|c|c|c|c|c|}
\hline No. & Assessment aspect & Frequency & Percentage (\%) & Average & Median \\
\hline \multirow[t]{5}{*}{1.} & Taste & & & & \\
\hline & Very bad $(1-3)$ & 1 & 1.9 & 7.4 & 8 \\
\hline & Bad (4-5) & 7 & 13.2 & & \\
\hline & Good (6-7) & 14 & 26.4 & & \\
\hline & Very good $(8-10)$ & 31 & 58.5 & & \\
\hline \multirow[t]{5}{*}{2.} & Aroma & & & & \\
\hline & Very bad (1-3) & 0 & 0.0 & 7.5 & 8 \\
\hline & $\operatorname{Bad}(4-5)$ & 7 & 13.2 & & \\
\hline & Good (6-7) & 19 & 35.9 & & \\
\hline & Very good(8-10) & 27 & 50.9 & & \\
\hline \multirow[t]{5}{*}{3.} & Product freshness & & & & \\
\hline & Very bad (1-3) & 0 & 0.0 & 6.8 & 7 \\
\hline & $\operatorname{Bad}(4-5)$ & 12 & 22.6 & & \\
\hline & Good (6-7) & 20 & 37.7 & & \\
\hline & Very good $(8-10)$ & 21 & 39.6 & & \\
\hline \multirow[t]{5}{*}{4.} & Color & & & & \\
\hline & Very dull (1-3) & 3 & 5.7 & 6.7 & 7 \\
\hline & Dull (4-5) & 9 & 17.0 & & \\
\hline & Clear (6-7) & 20 & 37.7 & & \\
\hline & Very clear $(8-10)$ & 21 & 39.6 & & \\
\hline \multirow[t]{5}{*}{5.} & Texture & & & & \\
\hline & Very soft (1-3) & 0 & 0.0 & 7.0 & 7 \\
\hline & Soft (4-5) & 7 & 13.2 & & \\
\hline & Solid (6-7) & 26 & 49.1 & & \\
\hline & Very solid (8-10) & 20 & 37.7 & & \\
\hline
\end{tabular}

Consumers who purchased processed products were generally to meet the daily needs. Stimulus affecting the consumers to purchase this product was the good taste, distinctive aroma, attractive appearance, clear color, and solid texture, therefore greatly affecting the consumer perception on salted fish product assessment. Table 2 shows a general overview of good fisheries product consumerassessment. Consumer preference on salted fish flavor was very good withdistinct aroma, good freshness level, clear color, and solid texture. Nonetheless, the product was processed through salting method. Fisheriesproduct obtained from the salting process using salt as preservative medium will show some water spots that can cause the product become moist followed with decreased nutritional value and organoleptic quality after keeping for four weeks. Therefore, an effort to improve the quality and durability of saltedRastrelligerbrachysomafish can be performed by giving additional spices to increase the salted fish durability.Rastrelligerkanagurta is a type of sea fish that is preferred by the community because of its nutritional content, easily obtained and has a delicious taste (Siregar, 2011). Rastrelligerkanagurta contains $22 \%$ protein and $70 \%$ omega-3 fatty acid content of the total fat in mackerel (Effendie, 2002).

\section{Brined Fish}

Consumer assessment onbrined fish was based on the good taste, aroma, and apperance along withclear color and solid texture. Consumer perception on the brined fish productwas good enough based on the average score and median value, presented on Table 3. 
Table 3. Consumer assessment on brined fish product quality

\begin{tabular}{|c|c|c|c|c|c|}
\hline No. & Assessment aspect & Frequency & Percentage (\%) & Average & Median \\
\hline \multirow[t]{5}{*}{1} & Taste & & & & \\
\hline & Very bad (1-3) & 0 & 0.0 & 8.4 & 8.5 \\
\hline & $\operatorname{Bad}(4-5)$ & 0 & 0.0 & & \\
\hline & Good (6-7) & 2 & 14.3 & & \\
\hline & Very good (8-10) & 12 & 85.7 & & \\
\hline \multirow[t]{5}{*}{2} & Aroma & & & & \\
\hline & Very bad (1-3) & 0 & 0.0 & 8.3 & 8 \\
\hline & $\operatorname{Bad}(4-5)$ & 0 & 0.0 & & \\
\hline & Good (6-7) & 2 & 14.3 & & \\
\hline & Very good(8-10) & 12 & 85.7 & & \\
\hline \multirow[t]{5}{*}{3} & Product freshness & & & & \\
\hline & Very bad (1-3) & 0 & 0.0 & 7.9 & 8 \\
\hline & $\operatorname{Bad}(4-5)$ & 1 & 7.1 & & \\
\hline & Good (6-7) & 2 & 14.3 & & \\
\hline & Very good (8-10) & 11 & 78.6 & & \\
\hline \multirow[t]{5}{*}{4} & Color & & & & \\
\hline & Very dull (1-3) & 0 & 0.0 & 7.4 & 8 \\
\hline & Dull (4-5) & 2 & 14.3 & & \\
\hline & Clear (6-7) & 4 & 28.6 & & \\
\hline & Very clear (8-10) & 8 & 57.1 & & \\
\hline \multirow[t]{5}{*}{5} & Texture & & & & \\
\hline & Very soft (1-3) & 1 & 7.1 & 7.9 & 8 \\
\hline & Soft (4-5) & 0 & 0.0 & & \\
\hline & Solid (6-7) & 4 & 28.6 & & \\
\hline & Very solid (8-10) & 9 & 64.3 & & \\
\hline
\end{tabular}

Raw materials used in brining production process were obtained from the brackishwater pond around the production site, while mackerel fish materials were obtained from Lampung and Jakarta. Producers purchased milkfish/mackerel fish with the price of Rp $20.000-22,000 / \mathrm{kg}$. The availability of milkfish in Lampung is now beginning to diminish as the brackishwater pond for milkfish culture is altered as vaname shrimp culture. Vaname shrimp culture can not be mixed with other commodities because shrimps are easily getting stressed.

The producer only purchased milkfish from around East Lampung, especially Labuhan Maringgai and Pasir Sakti Regency. They did not purchase the fish from other regions to keep the fish freshness level and cut the transportation distance.Brined milkfish production using unfreshed materials will result insoft and easily disrupted texture as supported by Guyon, Meynier, \& de Lamballerie (2016) and Guyon et al., (2016), who stated that the improvement of TBA (Thiobarbituric Acid) or cold storage periodwas caused by the occurrence of fat damage, making the increased rancidity due to oxidation reactions. The producers purchased milkfish based on each production needs. The number of milkfish that can be produced daily is around $15-50 \mathrm{~kg}$ of milkfish per day. The producer purchases $1 \mathrm{~kg}$ of fish containing 3-5 fish. The producer sells the milkfish brine with $\mathrm{Rp}$ 12,000-15,000/fish, while the price of mackerel fish comprised small size with Rp 10,000/three fish and large size withRp 20.000/three fish. The product assessment of brined fish was good, therefore finding no difficulties in marketing, however the improvement of brined fish product quality, making the brined fish product can be marketed to a larger scale (Lumban, Maulina, \& Gumilar, 2012). Some alternatives that can be performed is to maintain and improve the quality of brined fish as well as supervision and service along with increased production quantity, optimize production and welfare activities, producenew brined fish innovation Pindang, improving production technology and consumer approach, and making production budget. 


\section{Smoked Fish}

Smoking of fish in the traditional way is done using salt(Desniar, Poernomo, \& Wijatur, 2009), the use of seaweed ethanol extract Padina sp. (Husni \& Kusuma Brata, 2015), and fumigation (Dwiyitno \& Riyanto, 2007). Smoking method in traditional processing activity using direct combustionhas several weaknesses, namely inconsistent the product quality, accumulated harmful compounds, such as tar and benzopiren (Suroso, Utomo, Hidayati, \& Nuraini, 2018), air pollution, and low absorption efficiency. The method to reduce these weaknesses was perfomed using liquid smoke. Liquid smoke has advantages that are easy to apply, more uniform product flavor, more efficient in the use of smoky materials and carcinogenic compounds in the form of polycyclic aromatic compounds that formed can be eliminated(Simon, de la Calle, Palme, Meier, \& Anklam, 2005;Hattula, Elfving, Mroueh, \& Luoma, 2001). The consumer assessment on brined fish quality was generally good. Smoked fish from the race aspect was considered as having very good taste $(73.3 \%)$, aroma $(46.7 \%)$, then consumers also assessed the quality of fresh smoked fish product $(53.3 \%)$, as the color assessment was clear (53.33\%) and texture were assessed as to be solid and very solid (93.4\%). Consumer assessment on the quality of smoked fish product is shown on Table 4.

Table 4. Consumer Assessment on Smoked Fish Product Quality

\begin{tabular}{|c|c|c|c|c|c|}
\hline No. & Assessment aspect & Frequency & Percentage (\%) & Average & Median \\
\hline \multicolumn{6}{|c|}{ 1. Taste } \\
\hline & Very bad (1-3) & 1 & 6.7 & 7.9 & 8 \\
\hline & $\operatorname{Bad}(4-5)$ & 0 & 0.0 & & \\
\hline & Good (6-7) & 3 & 20.0 & & \\
\hline & Very good (8-10) & 11 & 73.3 & & \\
\hline \multicolumn{6}{|c|}{ Aroma } \\
\hline & Very bad (1-3) & 0 & 0.0 & 7.3 & 7 \\
\hline & $\operatorname{Bad}(4-5)$ & 2 & 13.3 & & \\
\hline & Good (6-7) & 7 & 46.7 & & \\
\hline & Very good(8-10) & 6 & 40.0 & & \\
\hline \multicolumn{6}{|c|}{ Product freshness } \\
\hline & Very bad (1-3) & 0 & 0.0 & 7.3 & 7 \\
\hline & $\operatorname{Bad}(4-5)$ & 1 & 6.7 & & \\
\hline & Good (6-7) & 8 & 53.3 & & \\
\hline & Very good (8-10) & 6 & 40.0 & & \\
\hline \multicolumn{6}{|c|}{ 4. Color } \\
\hline & Very dull (1-3) & 1 & 6.7 & 6.7 & 7 \\
\hline & Dull (4-5) & 1 & 6.7 & & \\
\hline & Clear (6-7) & 8 & 53.3 & & \\
\hline & Very clear $(8-10)$ & 5 & 33.3 & & \\
\hline \multicolumn{6}{|c|}{ 5. Texture } \\
\hline & Very soft (1-3) & 0 & 0.0 & 7.5 & 7 \\
\hline & Soft (4-5) & 1 & 6.7 & & \\
\hline & Solid (6-7) & 7 & 46.7 & & \\
\hline & Very solid (8-10) & 7 & 46.7 & & \\
\hline
\end{tabular}

\section{Fermented Fish}

Terasi (fish or shrimp paste) is one fermented fish (or shrimp) product that only undergo the salting treatment (without acid addition), then left for some times to begin the fermentation process. The fermentation process can take place due to the enzyme activity derived from the fish (or shrimp) body (Martasuganda, Agus, \& Sudirman, 2005). Terasi is liked in all Southeast Asian region, including Indonesia as it is affordable, available widely, and good taste and aroma. Terasi has fairly complete nutrient content, i.e protein, lipid, carbohydrate, mineral, calcium, phosphorus, iron, and water. In addition, Terasi contains vitamin B12 and amino acids. Aroma and flavor quality influence the fermentation period, as the longer the fermentation period, the higher theterasi quality. Moreover, 
Terasi flavor was affected by the raw materials used. The terasi flavor from the raw material of krill/shrimp different from the raw material of fish (Suprapti, 2002). The processing materials containing shrimp and prawns were obtained from muddy beaches. The raw materials were dried for six hours and was pounded and formed.

The production of Terasi needs additional salt ingredients, i.e $10 \mathrm{~kg}$ of krill was mixed with 1 $\mathrm{kg}$ of salt. Salt is used as fermentation process controller. Salt also serves as fish preservative as it has high osmotic pressure, causing the absorption process of waterin fish meat and microorganism cells that cause plasmolysis, thus the liquid cell is leaked and the microorganisms suffer mass mortality (Adawyah, 2008). Consumer assessment on the quality of fermented fish products was good. Consumers assessed that the fermentation product had very good taste $(47.1 \%)$, aroma $(76.5 \%)$, then the freshness level was good $(47.1 \%)$, clear color product (41.5 percent), and very solid texture $(47.1 \%)$. The consumer assessmenton the fish product quality the quality is shown on Table 5.

Table 5. Consumer Assessment on Fermented Fish (Terasi) Product Quality

\begin{tabular}{|c|c|c|c|c|c|}
\hline No. & Assessment aspect & Frequency & Percentage (\%) & Average & Median \\
\hline \multirow[t]{5}{*}{1.} & Taste & & & & \\
\hline & Very bad (1-3) & 0 & 0.0 & 7.5 & 7 \\
\hline & $\operatorname{Bad}(4-5)$ & 2 & 11.8 & & \\
\hline & Good (6-7) & 7 & 41.2 & & \\
\hline & Very good (8-10) & 8 & 47.1 & & \\
\hline \multirow[t]{5}{*}{2.} & Aroma & & & & \\
\hline & Very bad (1-3) & 0 & 0.0 & 8.4 & 8 \\
\hline & $\operatorname{Bad}(4-5)$ & 1 & 5.9 & & \\
\hline & Good (6-7) & 3 & 17.7 & & \\
\hline & Very good(8-10) & 13 & 76.5 & & \\
\hline \multirow[t]{5}{*}{3.} & Product freshness & & & & \\
\hline & Very bad (1-3) & 0 & 0.0 & 6.7 & 7 \\
\hline & $\operatorname{Bad}(4-5)$ & 4 & 23.5 & & \\
\hline & Good (6-7) & 8 & 47.1 & & \\
\hline & Very good (8-10) & 5 & 29.4 & & \\
\hline \multirow[t]{5}{*}{4.} & Color & & & & \\
\hline & Very dull (1-3) & 3 & 17.7 & 6.1 & 7 \\
\hline & Dull (4-5) & 3 & 17.7 & & \\
\hline & Clear (6-7) & 4 & 23.5 & & \\
\hline & Very clear (8-10) & 7 & 41.2 & & \\
\hline \multirow[t]{5}{*}{5.} & Texture & & & & \\
\hline & Very soft (1-3) & 3 & 17.7 & 6.8 & 7 \\
\hline & Soft (4-5) & 1 & 5.9 & & \\
\hline & Solid (6-7) & 5 & 29.4 & & \\
\hline & Very solid (8-10) & 8 & 47.1 & & \\
\hline
\end{tabular}

The best suited performances to improve Terasi widely marketing product are distinct taste when consumed, inrancid aroma, safe food additives color contains natural additives from the raw materials used to decrease health condition, price (price presented is based on the offered quality), clear nutrient components, hygiene, histamine or harmful compound contents, ease access to obtain product supply for wider market. These suggestions are expected to support the fermentation processing product business in sustainable condition.

\section{CONCLUSIONS}

Consumer preference observation in choosing the quality of traditional fisheries processing product, i.e salted, brined, smoked, and fermented fish.Successive consumer preferences were respectively: flavor, price, color, packaging type, and packaging color. Consumers assessed the 
processed products as having good taste, good aroma, freshly good, have distinct fragrance aroma, fresh appearance, and solid texture.

\section{REFERENCES}

Abedi, E., \& Sahari, M. A. (2014). Long-chain polyunsaturated fatty acid sources and evaluation of their nutritional and functional properties. Food Science and Nutrition, 2(5), 443-463. https://doi.org/10.1002/fsn3.121

Adawyah, R. (2008). Pengolahan Dan Pengawetan Ikan. Jakarta: PT Bumi Aksara.

Albarracín, W., Sánchez, I. C., Grau, R., \& Barat, J. M. (2011). Salt in food processing; usage and reduction: A review. International Journal of Food Science and Technology, 46, 46, 1329-1336. https://doi.org/10.1111/j.1365-2621.2010.02492.x

Angelova, B., \& Zekiri, J. (2011). Measuring Customer Satisfaction with Service Quality Using American Customer Satisfaction Model (ACSI Model). International Journal of Academic Research in Business and Social Sciences, 1(3), 27. https://doi.org/10.6007/ijarbss.v1i2.35

Apituley, Y. M., Stevanus, S., Risakotta, S. C., \& Hiariey, J. (2017). SIKAP DAN PERILAKU KONSUMEN IKAN ASAR DI KOTA AMBON. Jurnal Sosial Ekonomi Kelautan Dan Perikanan, 12(1), 121-132. https://doi.org/10.15578/jsekp.v12i1.2092

Badan Ketahanan Pangan. (2019). Statistik Ketahanan Pangan 2018. Jakarta: Badan Ketahanan Pangan, Kementerian Pertanian Indonesia.

Barberger-Gateau, P., Letenneur, L., Deschamps, V., Pérès, K., Dartigues, J. F., \& Renaud, S. (2002). Fish, meat, and risk of dementia: Cohort study. British Medical Journal, 325, 932-933. https://doi.org/10.1136/bmj.325.7370.932

Bonoco, A., \& Kurt Kaya, G. (2018). Effect of brine and dry salting methods on the physicochemical and microbial quality of chub (Squalius cephalus Linnaeus, 1758). Food Science and Technology, 38(1), 66-70. https://doi.org/10.1590/1678-457x.15717

Budiman, M. S. (2013). Teknik Penggaraman Dan Pengeringan. Jakarta: Jakarta, Departemen Pendidikan Nasiona.

Burger, J., Stephens, W. L., Boring, C. S., Kuklinski, M., Gibbons, J. W., \& Gochfeld, M. (1999). Factors in exposure assessment: Ethnic and socioeconomic differences in fishing and consumption of fish caught along the Savannah River. Risk Analysis, 19(3), 427-438. https://doi.org/10.1023/A:1007048628467

Can, M. F., Günlü, A., \& Can, H. Y. (2015). Fish consumption preferences and factors influencing it. Food Science and Technology, 35(2), 339-346. https://doi.org/10.1590/1678-457X.6624

Chung, J., \& Rao, V. R. (2012). A general consumer preference model for experience products: Application to internet recommendation. Journal of Marketing Research, 49(3), 289-305. https://doi.org/10.1509/jmr.09.0467

Conte, F., Passantino, A., Longo, S., \& Voslářová, E. (2014). Consumers' attitude towards fish meat. Italian Journal of Food Safety, 3(3), 1983. https://doi.org/10.4081/ijfs.2014.1983

Creusen, M. E. H., \& Schoormans, J. P. L. (2005). The different roles of product appearance in consumer choice. Journal of Product Innovation Management, 22(1), 63-81. https://doi.org/10.1111/j.0737-6782.2005.00103.x

Delima, I. S. D., Amanah, S., \& Tjitropranoto, P. (2016). Kompetensi Pemilik dan Pekerja Usaha Mikro Makanan Ringan tentang Mutu Produk di Cilegon dan Pandeglang, Provinsi Banten. Jurnal Penyuluhan, 12(2), 271-279. https://doi.org/10.25015/penyuluhan.v12i2.10905

Desniar, Poernomo, D., \& Wijatur, W. (2009). Pengaruh konsentrasi garam pada peda ikan kembung (rastrelliger sp.) Dengan fermentasi spontan. Jurnal Pengolahan Hasil Perikanan Indonesia, XII(1), 73-87.

Dowd, K., \& Burke, K. J. (2013). The influence of ethical values and food choice motivations on intentions to purchase sustainably sourced foods. Appetite, 69, 137-144. https://doi.org/10.1016/j.appet.2013.05.024

Dwiyitno, D., \& Riyanto, R. (2007). Studi Penggunaan Asap Cair Untuk Pengawetan Ikan Kembung (Rastrelliger neglectus) Segar. Jurnal Pascapanen Dan Bioteknologi Kelautan Dan Perikanan, 1(2), 143-148. https://doi.org/10.15578/jpbkp.v1i2.397

Effendi, I., Yanfika, H., Sumaryo, S., Listiana, I., Mutolib, A., \& Rahmat, A. (2019). Has Empowerment Program Been Appropriate for the Need of Fisheries Business Player?: Case Study in Lampung Province, Indonesia. International Journal of Multicultural and Multireligious Understanding, 6(4), 317. https://doi.org/10.18415/ijmmu.v6i4.982 
Effendie, Y. (2002). Biologi Perikanan. Padang: Yayasan Pustaka Nusatama.

Girsang, D. Y., Rangga, A., \& Susilawati. (2014). Kasus distribusi dan penggunaan formalin dalam pengawetan komoditi ikan laut segar (studi kasus di kota Bandar Lampung). Jurnal Teknologi Dan Industri Hasil Pertanian, 19(3), 218-228. https://doi.org/10.1186/1475-2875-12-4

Guyon, C., Meynier, A., \& de Lamballerie, M. (2016). Protein and lipid oxidation in meat: A review with emphasis on high-pressure treatments. Trends in Food Science and Technology, 50, 131143. https://doi.org/10.1016/j.tifs.2016.01.026

Hattula, T., Elfving, K., Mroueh, U. M., \& Luoma, T. (2001). Use of liquid smoke flavouring as an alternative to traditional flue gas smoking of rainbow trout fillets (Oncorhynchus mykiss). LWT

- Food Science and Technology, 34(8), 521-525. https://doi.org/10.1006/fst1.2001.0794

Hawkins, D. I., \& Mothersbaugh, D. L. (2010).Consumer Behaviour.Building Marketing Strategies (Eleventh E). New York: Mcgraw-Hill.

Herlambang, E. S., Manajemen, D., Manajemen, F. E., Studi, P., Profesional, M., Kecil, I., \& Pertanian, F. T. (2011). Kajian Perilaku Konsumen terhadap Strategi Pemasaran Teh Herbal di Kota Bogor. Manajemen IKM, 6(2), 85-93. https://doi.org/10.29244/mikm.6.2.85-93

Honkanen, P., Verplanken, B., \& Olsen, S. O. (2006). Ethical values and motives driving organic food choice. Journal of Consumer Behaviour, 5(5), 420-430. https://doi.org/10.1002/cb.190

Husni, A., \& Kusuma Brata, A. (2015). Peningkatan Daya Simpan Ikan Kembung dengan Ekstrak Etanolik Padina sp selama Penyimpanan Suhu Kamar. Jurnal Pengolahan Hasil Perikanan Indonesia, 18(1), 1-10. https://doi.org/10.17844/jphpi.2015.18.1.1

Kris-Etherton, P. M., Harris, W. S., \& Appel, L. J. (2002). Fish consumption, fish oil, omega-3 fatty acids, and cardiovascular disease. Circulation, 106(21), 2747-2757. https://doi.org/10.1161/01.CIR.0000038493.65177.94

Laisa, D. D., Sayekti, W. D., \& Nugraha, A. (2013). Analisis Harga Pokok Produksi dan Strategi Pengembangan Industri Pengolahan Ikan Teri Nasi Kering di Pulau Pasaran Kecamatan Teluk Betung Barat Kota Bandar Lampung. Jurnal Ilmu-Ilmu Agribisnis, 1(2), 111-117.

Listiana, I., Efendi, I., Mutolib, A., \& Rahmat, A. (2019). The behavior of Extension Agents in Utilizing Information and Technology to Improve the Performance of Extension Agents in Lampung Province. Journal of Physics: Conference Series, $1155(1$ (012004)), 1-10. https://doi.org/10.1088/1742-6596/1155/1/012004

Lumban, R., Maulina, I., \& Gumilar, I. (2012). Analisis Pengembangan Usaha Pemindangan Ikan Di Kecamatan Bekasi Barat. Jurnal Perikanan Dan Kelautan, 3(1), 17-24. https://doi.org/10.1017/CBO9781107415324.004

Manaf, M. (2007). Analisis Pemanfaatan Ruang Di Wilayah Pesisir Kecamatan Bontoharu Kabupaten Kepulauan Salayar. Plano Madani : Jurnal Perencanaan Wilayah Dan Kota, 4(2), 10-21.

Martasuganda, S., Agus, O., \& Sudirman. (2005). Teknologi Untuk Pemberdayaan Masyarakat Pesisir. Jakarta: Departemen Kelautan dan Perikanan.

McNaughton, S. A., Ball, K., Mishra, G. D., \& Crawford, D. A. (2008). Dietary Patterns of Adolescents and Risk of Obesity and Hypertension. The Journal of Nutrition, 138(2), 364-. https://doi.org/10.1093/jn/138.2.364

Murtidjo, B. (2008). Budidaya Udang Galah Sistem Monokultur. Yogyakarta: Kanisius.

Nadzan, N., Setiawan, B., \& Sukandar, D. (2008). Analysis of Fisheries Potential and Management in Food Security Perspective at Coastal Zone of West Lampung Regency. Jurnal Giizi Dan Pangan, 3(3), 149-155.

Pal, J., Shukla, B. N., Maurya, A. K., \& Verma, H. O. (2018). A review on role of fish in human nutrition with special emphasis to essential fatty acid. International Journal of Fisheries and Acquatic Studies, 6(2), 427-430.

Palmquist, D. L. (2009). Omega-3 Fatty Acids in Metabolism, Health, and Nutrition and for Modified Animal Product Foods. Professional Animal Scientist, 25(3), 207-249. https://doi.org/10.15232/S1080-7446(15)30713-0

Pieniak, Z., Verbeke, W., Perez-Cueto, F., Brunsø, K., \& De Henauw, S. (2008). Fish consumption and its motives in households with versus without self-reported medical history of CVD: A consumer survey from five European countries. BMC Public Health, 8(1), 306. https://doi.org/10.1186/1471-2458-8-306

Pratama, I. R., Rostini, I., \& Kurniawati, N. (2018). Pengembangan Produk Olahan Perikanan Skala Tradisional Berdasarkan Prosedur Terstandar. Jurnal Pengabdian Kepada Masyarakat, 2 (12), 
$524-529$.

Simon, R., de la Calle, B., Palme, S., Meier, D., \& Anklam, E. (2005). Composition and analysis of liquid smoke flavouring primary products. Journal of Separation Science, 28, 871-882. https://doi.org/10.1002/jssc.200500009

Siregar, R. (2011). Pengolahan Ikan Kembung. Jakarta: Pusat Penyuluhan Kelautan dan Perikanan.

Sugiarto, B. U., \& Subagio, H. (2014). Analisa Pengaruh Produk, Kualitas Pelayanan, Harga, Dan

Store Atmosphere Terhadap Minat Beli Di Dream Of Khayangan Art Resto Surabaya. Jurnal Manajemen Pemasaran Petra, 2(1), 1-14.

Suprapti, M. (2002). Membuat Terasi. Yogyakarta: Kanisius.

Suroso, E., Utomo, T. P., Hidayati, S., \& Nuraini, A. (2018). Pengasapan Ikan Kembung menggunakan Asap Cair dari Kayu Karet Hasil Redestilasi. Jurnal Pengolahan Hasil Perikanan Indonesia, 21(1), 42-53. https://doi.org/10.17844/jphpi.v21i1.21261

Suryawati, S. H., Saptanto, S., \& Putri, H. M. (2017). ANALISIS PREFERENSI KONSUMSI IKAN MENGHADAPI NATAL 2015 DAN TAHUN BARU 2016. Jurnal Kebijakan Sosial Ekonomi Kelautan Dan Perikanan, 6(1), 15-24. https://doi.org/10.15578/jksekp.v6i1.1614

Tjiptono. (2007). Strategi Pemasaran, edisi kedua. In Edisi Kedua. Yogyakarta: Andi. Yogyakarta: Andi Offset.

Verbeke, W., \& Vackier, I. (2005). Individual determinants of fish consumption: Application of the theory of planned behaviour. Appetite, 44(1), 67-82. https://doi.org/10.1016/j.appet.2004.08.006

Verbeke, W., \& Viaene, J. (1999). Beliefs, attitude and behaviour towards fresh meat consumption in

Belgium: Empirical evidence from a consumer survey. Food Quality and Preference, 10(6), 437-445. https://doi.org/10.1016/s0950-3293(99)00031-2

Waryati, G., Sunarno, A., Susilawati, T., \& Leilani, A. (2019). Potret Sistem Agribisnis Pengolahan Hasil Perikanan Di Pesisir Pantai Selatan Kabupaten Garut. Jurnal Penyuluhan, 15(2), 266-274. https://doi.org/10.25015/penyuluhan.v15i2.27735

Yanfika, H., Listiana, I., Mutolib, A., \& Rahmat, A. (2019). Linkages between Extension Institutions and Stakeholders in the Development of Sustainable Fisheries in Lampung Province. Journal of Physics: Conference Series, 1155(1), 1-6. https://doi.org/10.1088/1742-6596/1155/1/012014

Yanfika, Helvi, Amanah, S., Fatchiya, A., \& Asngari, P. S. (2018). Strategy to Develop Traditional Fishery Business in Implementing the Principle of Sustainable Business. Jurnal Penyuluhan, 14(2), 271-280. 